Przegląd Prawa Konstytucyjnego

-------ISSN 2082-1212--------

DOI 10.15804/ppk.2017.05.11

$-\mathrm{Nr} 5(39) / 2017--------$

\title{
Krzysztof Grajewski
}

\section{Ustanie członkostwa w Krajowej Radzie Sądownictwa osoby powołanej przez Prezydenta RP a zakończenie kadencji głowy państwa (uwagi na tle wyroku Sądu Najwyższego z 15 marca 2011 r., III KRS 1/11)²}

Słowa kluczowe: Krajowa Rada Sądownictwa, Prezydent Rzeczypospolitej Polskiej Keywords: National Council of the Judiciary, President of the Republic of Poland

\section{Streszczenie}

Opracowanie jest poświęcone problematyce zakończenia kadencji osoby powołanej w skład Krajowej Rady Sądownictwa przez Prezydenta Rzeczypospolitej Polskiej. W konkluzjach stwierdza się, że kadencja tej osoby jest uzależniona od kadencji Prezydenta w ten sposób, że wygasa ona najpóźniej w ciągu trzech miesięcy po zakończeniu kadencji Prezydenta, niezależnie od przyczyn, z powodu których głowa państwa zakończy sprawowanie swojego urzędu.

\section{Summary}

\section{Termination of the membership in the National Council of the Judiciary of the person appointed by the President and the termination of the President's Office (Remarks on the judgment of the Supreme Court of 15 March 2011, III KRS 1/11)}

The article discusses the issue of termination of office of a person appointed to the National Council of the Judiciary by the President of the Republic of Poland. The conclu-

1 Autor jest profesorem nadzwyczajnym w Katedrze Prawa Konstytucyjnego i Instytucji Politycznych Wydziału Prawa iAdministracji Uniwersytetu Gdańskiego.E-mail:prakg@ug.edu.pl. 2 OSNP 2012 r, nr 9-10, poz. 131. 
sions state that the term of office of this person is directly dependent on the President's term of office. It expires not later than three months after the end of the President's term of office, regardless of the reasons for the President's termination of his office.

\section{I.}

Krajowa Rada Sądownictwa (dalej: „KRS” lub „Rada”) została wprowadzona do polskiego porządku konstytucyjnego w 1989 r. w wyniku uchwalonych wówczas zmian konstytucji PRL ${ }^{3}$. W tzw. noweli kwietniowej ${ }^{4}$, za pomocą której zrealizowano m.in. stanowczo artykułowany podczas obrad Okrągłego Stołu przez stronę opozycyjno-solidarnościową postulat powołania niezależnej rady sądownictwa ${ }^{5}$, uznawanej za niezbędny element konstrukcji ustrojowej zapewniającej niezawisłość sędziowską i niezależność sądów, zawarto dwa przepisy poświęcone Krajowej Radzie Sądownictwa. Artykułem 1 pkt 17 przywołanej ustawy znowelizowano art. 60 konstytucji PRL wprowadzając nowy ust. 1, zgodnie z którym sędziowie mieli być powoływani na wniosek KRS przez Prezydenta oraz nowy ust. 3, zgodnie z którym uprawnienia, skład i sposób działania Rady miały zostać określone w ustawie.

Pierwsza ustawa o Krajowej Radzie Sądownictwa została uchwalona jeszcze w 1989 r. ${ }^{6}$ W art. 4 ust. 1 tej ustawy zrealizowano dyspozycję przepisu konstytucyjnego, ustalając skład tego organu. Spośród dwudziestu czterech członków Rady, jednego wskazywał Prezydent, a kadencja KRS miała trwać

3 Konstytucja Polskiej Rzeczypospolitej Ludowej uchwalona przez Sejm Ustawodawczy 22 lipca 1952 r. (t. j. Dz.U. 1976, Nr 7, poz. 36 ze zm.).

4 Ustawa z 7 kwietnia 1989 r. o zmianie Konstytucji Polskiej Rzeczypospolitej Ludowej (Dz.U.nr 19, poz. 101).

5 Zob.przykładowo Sprawozdanie z posiedzeń Podzespołu do spraw Reformy Prawa i Sąów „Okragtego Stotu” (brak miejsca i daty wydania) s. 2 i s. 10, http://okragly-stol.pl/wp-content/ uploads/2014/04/05_sprawozdanie_prawo_sady.pdf(27.07.2017), orazStanowisko wsprawie reform politycznych (brak miejsca i daty wydania), s.9-10, http://okragly-stol.pl/wp-content/ uploads/2014/04/01_stanowisko_polityka.pdf(27.07.2017).

6 Ustawa z 20 grudnia 1989 r. (Dz.U. Nr 73, poz. 435 ze zm.). 
cztery lata (art. 5). W ustawie nie było żadnych innych przepisów, które określały status osoby powoływanej przez Prezydenta, w tym także możliwość ewentualnego odwołania takiej osoby. Choć nie wynikało to bezpośrednio z przepisów konstytucyjnych, to jednak można stwierdzić, że obecność w Radzie przedstawiciela Prezydenta podkreślała takie ukształtowanie składu KRS, które miało na celu zapewnienie udziału w Radzie osób wskazanych przez wszystkie organy, które były w jakiś sposób kompetencyjnie związane $\mathrm{z}$ sądownictwem.

W czasie obowiązywania pierwszej ustawy o KRS została uchwalona i weszła w życie tzw. mała konstytucja z 1992 r. ${ }^{7}$ Znalazł się w niej tylko jeden przepis odnoszący się do Rady: art. 42 stanowił, że Prezydent powołuje sędziów na wniosek Krajowej Rady Sądownictwa. W dalszym ciągu obowiązywał przywołany wyżej art. 60 ust. 3 konstytucji z 1952 r., co skutkowało tym, że przepisy dotyczące składu Rady wynikały z ustawy, która - pomimo zmian art. 4 ust. 1 wprowadzonych w 1990 r. ${ }^{8}$ - wciąż przewidywała kompetencję Prezydenta do wskazania jednego z członków Rady. Warto jednak zaznaczyć, że liczba członków KRS wzrosła wówczas do dwudziestu sześciu.

II.

W porównaniu do uprzednich unormowań konstytucyjnych, w konstytucji RP z 1997 r. ${ }^{9}$ zawarto znacznie rozszerzoną regulację problematyki Krajowej Rady Sądownictwa. Zgodnie z art. 187 ust. 1, w skład Rady wchodzi od tamtego czasu dwudziestu pięciu członków, w tym także osoba powołana przez Prezydenta Rzeczypospolitej, przy czym w KRS w dalszym ciągu zasiadają osoby powoływane przez organy wszystkich władz zaangażowanych w sprawy

7 Ustawa konstytucyjna z 17 października 1992 r. o wzajemnych stosunkach między władzą ustawodawczą i wykonawczą Rzeczypospolitej Polskiej oraz o samorządzie terytorialnym (Dz.U. Nr 84, poz. 426 ze zm.).

$8 \quad$ Zob. art. 7 pkt 3 ustawy z 13 lipca 1990 r. o powołaniu sądów apelacyjnych oraz o zmianie ustawy - Prawo o ustroju sądów powszechnych, Kodeks postępowania cywilnego, Kodeks postępowania karnego, o Sądzie Najwyższym, o Naczelnym Sądzie Administracyjnym oraz o Krajowej Radzie Sądownictwa (Dz.U. Nr 53, poz. 306).

9 Konstytucja Rzeczypospolitej Polskiej z 2 kwietnia 1997 r. (Dz.U. Nr 78, poz. 483 ze zm.). 
sądownictwa. W 2001 r. uchwalono drugą ustawę o KRS ${ }^{10}$, w której skład tego organu został dostosowany do nowych przepisów konstytucyjnych. Ponadto w ustawie nie było już przepisów, które ustanawiałyby kadencję całej Rady; pojawiło się natomiast uregulowanie odnoszące się do członka KRS powołanego przez Prezydenta. Zgodnie z art. 5 ust. 1, osoba powołana przez głowę państwa miała pełnić swoją funkcję bez oznaczania okresu kadencji i mogła być odwołana w każdym czasie. To rozwiązanie można uznać za konsekwencję nieokreślenia w przepisach konstytucyjnych kadencji osoby powoływanej przez Prezydenta w przeciwieństwie do wybieranych do Rady sędziów, których kadencja trwa cztery lata (por. art. 187 ust. 1 pkt 1 in fine i ust. 3 konstytu$\mathrm{cji}^{11}$ ). Ponadto, zgodnie $\mathrm{z}$ art. 5 ust. 2 ustawy z 2001 r., mandat osoby powołanej przez Prezydenta wygasał najpóźniej w ciągu trzech miesięcy po zakończeniu kadencji Prezydenta.

Na tle tego uregulowania w literaturze zauważano, że pozycja „osoby powoływanej przez Prezydenta jest szczególna, gdyż jest ona desygnowana w sposób dyskrecjonalny oraz może być przez Prezydenta w każdym czasie (...) odwołana”. W kontekście regulacji art. 5 ust. 2 podkreślano, że kadencja osoby wskazanej przez głowę państwa „trwa przez okres powołania. Gdyby Prezydent, którego kadencja upłynęła, nie odwołał osoby przez siebie powołanej i gdyby nie uczynił tego nowo wybrany Prezydent, a osoba ta nie zrzekłaby się członkostwa w Radzie, jej mandat wygasa z upływem 3 miesięcy po zakończeniu kadencji Prezydenta, który ją powołał. Udział w Radzie osoby powoływanej przez Prezydenta łączy się zatem z kadencją Prezydenta"12, a brak automatycznego wygaśnięcia członkostwa a KRS w przypadku zakończenia kadencji Prezydenta w postaci unormowania przedłużającego sprawowanie funkcji w Radzie w trzymiesięcznym okresie po zakończeniu kadencji głowy państwa, można było uznać za świadome działanie ustawodawcy, który w ten sposób stworzył warunki do działania Rady w pełnym składzie w pierwszym

10 Ustawa z 27 lipca 2001 r. o Krajowej Radzie Sądownictwa (t. j. Dz.U. 2010, Nr 11, poz. 67 ze zm.).

11 Należy jednak podkreślić, że również wiryliści (Pierwszy Prezes Sądu Najwyższego, Prezes Naczelnego Sądu Administracyjnego i Minister Sprawiedliwości) pełnią funkcje w KRS bez oznaczania kadencji.

12 T. Ereciński, J. Gudowski, I. Iwulski, Prawo o ustroju sądów powszechnych. Ustawa o Krajowej Radzie Sądownictwa. Komentarz, Warszawa 2010, s. 710. 
okresie po zakończeniu kadencji urzędującej głowy państwa. Warto dodać, że chociaż w przypadku osoby powołanej przez Prezydenta mamy do czynienia $\mathrm{z}$ osobistą delegacją określonej osoby przez głowę państwa, która ma, jak już wskazano, prawo ją odwołać w każdym czasie, to jednak osoba ta nie jest traktowana jak przedstawiciel, czy reprezentant Prezydenta ${ }^{13}$, podobnie jak np. wybierani do Rady sędziowie (art. 187 ust. 1 pkt 2 konstytucji RP) nie są przedstawicielami zgromadzeń sędziów. Należy jeszcze dodać, że wbrew ugruntowanej praktyce ${ }^{14}$ związanej z powoływaniem (i odwoływaniem) przez Prezydenta członka KRS, ta kompetencja od 1992 r., a więc od wejścia w życie małej konstytucji, nie jest prerogatywą, ale tzw. zwykłym uprawnieniem głowy państwa ${ }^{15}$, co oznacza, że podlega kontrasygnacie Prezesa Rady Ministrów (aktualnie na podstawie art. 187 ust. 1 pkt $1 \mathrm{w} \mathrm{zw.} \mathrm{z} \mathrm{art.} 144$ ust. 2 i ust. 3 konstytucji).

\section{III.}

10 kwietnia 2010 r. w katastrofie lotniczej pod Smoleńskiem poniósł śmierć Lech Kaczyński, ówcześnie urzędujący Prezydent Rzeczypospolitej Polskiej. Nastąpiła zatem sytuacja opisana w art. 131 ust. 1 pkt 1 konstytucji. Przepis ten stanowi, że w razie śmierci głowy państwa, do czasu wyboru nowego Prezydenta, Marszałek Sejmu tymczasowo wykonuje obowiązki głowy państwa (w wypadku, gdy Marszałek Sejmu nie może wykonywać obowiązków Pre-

13 L. Garlicki, uwaga 5 do art. 187, [w:] Konstytucja Rzeczypospolitej Polskiej. Komentarz, t. IV, red. L. Garlicki, Warszawa 2005.

14 Zob. przykładowo niekontrasygnowane postanowienia Prezydenta Rzeczypospolitej Polskiej z 30 września 2015 r. nr 1131.35.2015 o powołaniu w skład Krajowej Rady Sądownictwa (M.P. poz. 1104) oraz nr 1131.34.2015 o odwołaniu ze składu Krajowej Rady Sądownictwa (M.P. poz. 1103).

15 Więcej na ten temat zob. K. Grajewski, Prezydencka kompetencja do powoływania członka Krajowej Rady Sądownictwa - prerogatywa czy uprawnienie zwykłe?, [w:] Zagadnienia prawa konstytucyjnego. Polskie i zagraniczne rozwiąania ustrojowe. Księga jubileuszowa dedykowana Profesorowi Dariuszowi Góreckiemu w siedemdziesiątą rocznicę urodzin, red. K. Skotnicki, K. Składowski, A. Michalak, Łódź 2016, s. 172-179. Podobny pogląd prezentuje w przywołanym wyżej w przypisie 13 komentarzu do konstytucji RP L. Garlicki. Odmienny pogląd wyrażają T. Ereciński, J. Gudowski, J. Iwulski, op.cit., s. 711 oraz R. Pęk, uwaga 5 do art. 8, [w:] M. Niezgódka-Medek, R. Pęk, Krajowa Rada Sądownictwa. Komentarz, Warszawa 2013. 
zydenta, obowiązki te przejmuje Marszałek Senatu; zob. art. 131 ust. 3 konstytucji RP).

Należy jeszcze dodać, że śmierć piastuna najwyższego urzędu w państwie nie jest jedynym przypadkiem, gdy Marszałek Sejmu (Senatu) przejmuje tymczasowe wykonywanie obowiązków prezydenta. Do takich przyczyn w art. 131 ust. 2 zaliczono również zrzeczenie się urzędu (pkt 2), stwierdzenie nieważności wyboru Prezydenta, a także inne przyczyny nieobjęcia urzędu po wyborze (pkt 3), uznanie przez Zgromadzenie Narodowe trwałej niezdolności Prezydenta Rzeczypospolitej do sprawowania urzędu ze względu na stan zdrowia, uchwałą podjętą większością co najmniej 2/3 głosów ustawowej liczby członków Zgromadzenia Narodowego (pkt 4) oraz złożenie Prezydenta z urzędu orzeczeniem wydanym przez Trybunał Stanu (pkt 5).

W literaturze zgodnie uznaje się, że zaistnienie którejkolwiek z uregulowanych w art. 131 ust. 2 konstytucji RP przyczyn objęcia zastępstwa przez Marszałka Sejmu (Marszałka Senatu) jest równoznaczne z tzw. opróżnieniem urzędu Prezydenta (sede vacante), czyli trwałą niemożnością (niezdolnością) do sprawowania urzędu ${ }^{16}$. Inaczej mówiąc, opróżnienie urzędu Prezydenta „oznacza trwałe i definitywne zakończenie wykonywania przez osobę piastującą tę funkcję obowiązków głowy państwa przed upływem 5-letniej kadencji. (...) Opróżnienie urzędu (...) skutkuje zakończeniem kadencji Prezydenta RP przed czasem"17.

Opróżnienie urzędu Prezydenta nie jest zatem tożsame z czasową niezdolnością do sprawowania urzędu Prezydenta (sede plena), również regulowaną w przepisach polskiej ustawy zasadniczej. Dla niniejszych rozważań istotna jest konstatacja, w myśl której czasowa niezdolność do sprawowania urzędu Prezydenta nie ma trwałego charakteru. Jest to sytuacja z definicji przejściowa (tymczasowa), a więc nie powoduje ona ani przerwania, ani tym bardziej zakończenia kadencji głowy państwa. Skutkuje jedynie czasowym niewyko-

16 Zob. przykładowo: Z. Witkowski, Prezydent Rzeczypospolitej Polskiej, [w:] Prawo konstytucyjne, red. Z. Witkowski, Toruń 2006, s. 413; R. Balicki, [w:] Komentarz. Konstytucja Rzeczypospolitej Polskiej, red. M. Haczkowska, Warszawa 2014, s. 337; B. Banaszak, Konstytucja Rzeczypospolitej Polskiej. Komentarz, Warszawa 2009, s. 656.

${ }_{17}$ E. Popławska, Opróżnienie urzędu Prezydenta RP (art. 128, 131), [w:] Konstytucja Rzeczypospolitej Polskiej. Komentarz encyklopedyczny, red. W. Skrzydło, S. Grabowska, R. Grabowski, Warszawa 2009, s. 315-316. 
nywaniem uprawnień i obowiązków głowy państwa przez osobę piastującą ten urząd (zob. art. 131 ust. 1 i art. 145 ust. 3 konstytucji).

Drugim skutkiem opróżnienia urzędu Prezydenta, a więc przedterminowego, definitywnego zakończenia kadencji głowy państwa, jest obowiązek zarządzenia wyborów na urząd Prezydenta. Obowiązek ten nie wymaga uzasadnienia - jak najszybciej powinien zostać bowiem przywrócony regularny stan funkcjonowania państwa ${ }^{18}$. Stosownie do art. 128 ust. 2 konstytucji RP, Marszałek Sejmu jest zobowiązany do zarządzenia wyborów nie później niż w czternastym dniu po opróżnieniu urzędu. Data wyborów powinna być wyznaczona w dzień wolny od pracy, przypadający w ciągu 60 dni od dnia zarządzenia wyborów. Taka sama regulacja znajduje się w art. 289 ust. 2 kodeksu wyborczego ${ }^{19}$.

\section{IV.}

W chwili śmierci Prezydenta Lecha Kaczyńskiego w składzie Krajowej Rady Sądownictwa zasiadała osoba powołana przez Prezydenta 6 stycznia 2006 r. $^{20}$ Osoba ta nie została odwołana ze składu Rady w czasie trzymiesięcznego terminu, o którym była mowa w art. 5 ust. 2 ustawy o KRS z 2001 r. Odwołanie nastąpiło bowiem dopiero 21 września $2010 \mathrm{r}^{21}$, a więc w ponad dwa miesiące po upływie wymienionego wyżej terminu. Odwołania dokonał nowo wybrany Prezydent RP. Opisywana sytuacja wzbudziła wówczas wątpliwości m.in. w publicystyce prawniczej ${ }^{22}$, a Prezydium Krajowej Rady Sądownictwa wydało nawet oświadczenie, w którym stwierdziło, że zgodnie „Z art. 131 ust. 2 konstytucji RP Marszałek Sejmu tymczasowo, do czasu wyboru nowego Prezydenta (...), wykonuje obowiązki Prezydenta (...) m.in. w razie śmierci głowy państwa.

\footnotetext{
18 Ibidem, s. 317.

19 Ustawa z 5 stycznia 2011 r. - Kodeks wyborczy (t. j. Dz.U. 2017, poz. 15 ze zm.).

20 Zob. postanowienie Prezydenta Rzeczypospolitej Polskiej z 6 stycznia 2006 r. nr 113.3 .06 o powołaniu w skład Krajowej Rady Sądownictwa (M.P. nr 10, poz. 127).

${ }_{21}$ Zob. postanowienie Prezydenta Rzeczypospolitej Polskiej z 21 września 2010 r. nr 1131.31.10 o odwołaniu ze składu Krajowej Rady Sądownictwa (M.P. Nr 74, poz. 941).

22 Więcej na ten temat zob. K. Grajewski, M. Pułło, Skutki wadliwości uchwał Krajowej Rady Sądownictwa w kontekście wygaśnięcia mandatu jednego zjej członków w związkuz opróżnieniem urzędu Prezydenta RP, „Krajowa Rada Sądownictwa” 2011, nr 1, s. 5 i przywołaną tam literaturę.
} 
Oznacza to, że Marszałek nie wykonuje wtedy nowej, przejściowej kadencji, lecz w ramach ciągłości władzy państwowej wykonuje obowiązki w zakresie zmarłej głowy państwa, kontynuując kadencję, aż do zaprzysiężenia nowego Prezydenta. (...) Marszałek Sejmu, a potem (...) Prezydent RP (...) mógł odwołać przedstawiciela Prezydenta w Krajowej Radzie Sądownictwa (...) w każdym czasie, a skoro tego nie uczynił (...) mandat wygaśnie po trzech miesiącach od zaprzysiężenia nowego Prezydenta, czyli z dniem 6 listopada 2010 r." ${ }^{\text {"2 }}$

W przedstawionym oświadczeniu zwracają uwagę co najmniej dwie kwestie. Po pierwsze, jak się wydaje, Prezydium Rady uznało, że Marszałek Sejmu tymczasowo wykonujący obowiązki Prezydenta w wypadku opróżnienia urzędu głowy państwa, kontynuuje kadencję zmarłego Prezydenta. Po drugie, Prezydium zdaje się odnosić trzymiesięczny termin określony w art. 5 ust. 2 ustawy o KRS z 2001 r. nie do chwili śmierci Prezydenta L. Kaczyńskiego, ale do dnia zaprzysiężenia nowo wybranego Prezydenta. Należy więc zgodzić się z poglądem K. Szczuckiego, który zauważył, że przyjęto wówczas „interpretację, według której Marszałek Sejmu, pełniąc obowiązki Prezydenta RP, niejako kontynuował jego kadencję, co zdaniem zwolenników tej interpretacji oznaczało, że nie zaktualizowała się hipoteza stosownej normy z ustawy regulującej działalność Rady"24.

Problematyka ustania członkostwa osoby powołanej do Krajowej Rady Sądownictwa stała się również przedmiotem rozważań Sądu Najwyższego w wyroku z 15 marca 2011 r. Wyrok ten zapadł na skutek złożonego do Sądu Najwyższego odwołania od uchwały Krajowej Rady Sądownictwa, która postanowiła nie przedstawiać Prezydentowi RP kandydatury sędziego jednego $\mathrm{z}$ sądów rejonowych $\mathrm{z}$ wnioskiem o powołanie go do pełnienia urzędu na stanowisku sędziego Wojewódzkiego Sądu Administracyjnego. Jeden z zarzutów podniesionych w odwołaniu odnosił się do uczestnictwa w posiedzeniu KRS 7-10 września 2010 r. osoby powołanej przez Prezydenta w sytuacji, gdy zgodnie z art. 5 ust. 2 ustawy z 2001 r. mandat tej osoby wygasł 10 lipca 2010 r. (trzy miesiące po śmierci Prezydenta, a więc trzy miesiące po zakończeniu kadencji głowy państwa).

23 Zob. Oświadczenie Prezydium Krajowej Rady Sądownictwa z 21 września 2010 r. (maszynopis).

${ }_{24}$ K. Szczucki, [w:] Konstytucja RP. Tom II. Komentarz. Art. 87-243, red. M. Safjan, L. Bosek, Warszawa 2016, s. 1123. 
Sąd Najwyższy, odnosząc się do tego zarzutu, przeprowadził bardzo obszerny wywód. Sąd Najwyższy m.in. „miał na uwadze (...), że mandatariuszka Prezydenta RP (...) została (...) odwołana (...) w dniu 21 września 2010 r. przez Prezydenta (...) Bronisława Komorowskiego. Z postanowienia Prezydenta (...) wynika (...), że aż do tego odwołania Prezydent uznawał trwanie (ciągłość) mandatu powierzonego (...) przez poprzedniego Prezydenta (...)”. Zdaniem Sądu Najwyższego, odmienny pogląd osoby odwołującej się od uchwały KRS wynika z niesłusznego założenia, że do wygaśnięcia mandatu osoby powołanej przez Prezydenta miał wówczas zastosowanie wyłącznie art. 5 ust. 2 ustawy o KRS z 2001 r. „i to tylko tak rozumiany, że śmierć Prezydenta powinna mieć znaczenie takie same jak zakończenie kadencji Prezydenta. Ustalenie w art. 5 ust. 2 ustawy (...), że mandat osoby powołanej przez Prezydenta wygasa najpóźniej w ciągu trzech miesięcy po zakończeniu kadencji Prezydenta nie stanowi działającej w pełni automatycznie normy prawnej, a przeciwnie jest częścią (...) wtórną i tylko uzupełniającą zasady zawartej w art. 5 ust. 1 ustawy, że osoba powołana przez Prezydenta (...) pełni swoje funkcje w Radzie bez oznaczenia okresu kadencji i może być odwołana w każdym czasie. Z kolei powyższa zasada wyrażająca szczególną pozycję osoby powoływanej (...) przez Prezydenta, że jest ona mandatariuszem desygnowanym dyskrecjonalnie i tak samo dyskrecjonalnie, przez Prezydenta w każdym czasie może być odwołana - wynika z normy zawartej w konstytucji RP (...)"25.

W dalszej części wywodu Sąd Najwyższy ponownie zaakcentował związek mandatu osoby powołanej w skład KRS przez głowę państwa „z wolą Prezydenta spełniającego swój urząd”. Następnie zaś stwierdził, że ponieważ przepis art. 5 ust. 2 ustawy nie stanowi pełnej i zamkniętej regulacji, to „mylące staje się poszukiwanie (...) rozwiązania problemu zakończenia mandatu osoby powołanej przez Prezydenta w związku ze śmiercią Prezydenta” poprzez utożsamianie zgonu Prezydenta z pojęciem zakończenia jego kadencji w rozumieniu art. 5 ust. 2 ustawy o KRS z 2001 r. Ponadto Sąd Najwyższy zauważył, że w sytuacji, w której „Prezydent, którego kadencja upłynęła, nie odwołałby osoby przez siebie powołanej i jeżeli nie uczyniłby tego nowo wybrany Prezydent, to jej mandat wygasa $\mathrm{z}$ upływem trzech miesięcy po zakończeniu kadencji Prezydenta, który ją powołał”. Zdaniem Sądu Najwyższego w tym

25 Zob. uzasadnienie wyroku. 
właśnie wyraża się istota regulacji art. 5 ust. 2 ustawy o KRS z 2001 r. Chodzi bowiem o to, że „mandat osoby powoływanej ma wynikać z prerogatywy urzędującego Prezydenta; regulacja ustawowa określa sytuację, która ma zapewniać skutecznie realizację (...) prerogatywy każdemu Prezydentowi. Śmierć Prezydenta Rzeczypospolitej (...) spowodowała niedokończenie jego pięcioletniej kadencji. Do czasu wyboru nowego Prezydenta Rzeczypospolitej obowiązki Prezydenta wykonywał tymczasowo Marszałek Sejmu”. Dlatego też, zdaniem Sądu Najwyższego, dopiero po upływie okresu, w którym Marszałek Sejmu (Marszałek Senatu) zastępuje zmarłego Prezydenta, będzie można mówić o zakończeniu kadencji głowy państwa w rozumieniu art. 5 ust. 2 ustawy o KRS z 2001 r., „bo dopiero wówczas (...) powstała sytuacja zapewniająca regulację prerogatywy powołania członka Krajowej Rady Sądownictwa przez Prezydenta (...) Bronisława Komorowskiego, którego kadencja rozpoczęła się (...) w dniu objęcia przez niego urzędu po upływie (...) okresu «dokończenia» kadencji Prezydenta (...) Lecha Kaczyńskiego”. W konkluzji Sąd Najwyższy uznał zatem, że osoba powołana w 2006 r. do KRS przez Prezydenta Lecha Kaczyńskiego miała „niebudzący wątpliwości mandat” do zasiadania w Radzie także po 10 lipca 2010 r. $^{26}$

V.

Trzeba przyznać, że analiza przywołanego wywodu nieuchronnie prowadzi do przeświadczenia, że Sąd Najwyższy stara się w swoim rozumowaniu udowodnić to, czego w żaden sposób udowodnić nie można. W przywołanym fragmencie uzasadnienia wyroku nie budzi wątpliwości w zasadzie tylko jeden wątek. Słusznie bowiem Sąd Najwyższy podkreśla zarówno związek osoby nominowanej przez Prezydenta z głową państwa, jak też uzależnienie kadencji „prezydenckiego” członka KRS od woli Prezydenta. To oczywista konstatacja, bo w przepisach ustawy o KRS z 2001 r. ustanowiono wyraźnie kompetencję głowy państwa do odwołania takiej osoby w dowolnym momencie. Ponadto pełnienie funkcji w KRS przez tę osobę następowało bez oznaczenia kadencji (art. 5 ust. 1). Jest oczywiste, że to rozwiązanie w znakomity sposób korelowało z prawem do odwołania prezydenckiego nominata.

26 Ibidem. 
Zdecydowanej krytyki wymaga ta część wywodu, w której Sąd Najwyższy próbuje nadać jakieś szczególne znaczenie użytemu w art. 5 ust. 2 ustawy o KRS z 2001 r. pojęciu kadencji Prezydenta. Należy przypomnieć, że kadencja głowy państwa jest w polskim prawie określona w przepisach ustawy zasadniczej. Stosownie do art. 127 ust. 2 konstytucji RP, Prezydent jest wybierany na pięcioletnią kadencję. Rozpoczyna się ona w dniu objęcia przez niego urzędu (art. 128 ust. 1). Zasadniczym powodem zakończenia kadencji głowy państwa jest upływ czasu, na który została ona wybrana. Jednakże poza tą sytuacją, w przepisach konstytucyjnych przewidziano, o czym była już wyżej mowa, sytuacje nadzwyczajne. Uregulowano je wyczerpująco w art. 131 ust. 2. Należy powtórzyć, że zaistnienie którejkolwiek z tych sytuacji powoduje opróżnienie urzędu Prezydenta, co oznacza zakończenie kadencji urzędującej głowy państwa przed upływem jej konstytucyjnego terminu ${ }^{27}$. Nie ma więc mowy o tym, by Marszałek Sejmu (Marszałek Senatu) tymczasowo wykonujący obowiązki Prezydenta w trybie art. 131 ust. 2 w zw. z ust. 3 konstytucji RP, kontynuował kadencję zmarłego Prezydenta, jak to stwierdzono w przywołanym wyżej oświadczeniu Prezydium KRS, a także w uzasadnieniu wyroku Sądu Najwyższego. W związku z tym nie można uznać, że użyte w art. 5 ust. 2 in fine ustawy o KRS z 2001 r. sformułowanie odnoszące się do zakończenia kadencji głowy państwa mogło być rozumiane w ten sposób, że byłoby tożsame z momentem, w którym kończy się okres tymczasowego wykonywania obowiązków Prezydenta przez uprawnioną osobę. Nie można przecież interpretować regulacji ustawowych wprost w opozycji do przepisów konstytucyjnych.

Nieprawidłowość wykładni dokonanej przez Sąd Najwyższy uwidacznia się wyjątkowo wyraziście w odniesieniu do konkretnej przyczyny opróżnienia urzędu Prezydenta, która wystąpiła w 2010 r. Chodzi oczywiście o śmierć urzędującego Prezydenta (art. 131 ust. 2 pkt 1 konstytucji RP). Trudno jest bowiem dowodzić, że polskie prawo przewiduje trwanie kadencji osoby zmarłej. Warto podkreślić, że w polskim rozwiązaniu ustrojowym funkcjonuje zasada związania mandatu głowy państwa z osobą wybranego Prezydenta. „Oznacza ona, że określony w Konstytucji czas trwania kadencji jest (...) stały i przypisany do osoby. Należy rozumieć to w ten sposób, że urzędowi pre-

27 Por. B. Banaszak, op.cit., s. 656. 
zydenta przypisany jest element władzy osobistej, ściśle związanej” z osobą, będącą w konkretnym momencie piastunem tego urzędu. Wynika z tego, że „Wraz z zakończeniem urzędowania (...) kończy się mandat określonego prezydenta i wygasa jego kadencja" ${ }^{28}$. Konsekwencją takiego stanu rzeczy nie jest zatem kontynuacja kadencji zmarłej głowy państwa, ale tymczasowe wykonywanie obowiązków Prezydenta RP przez osobę uprawnioną do tego $\mathrm{w}$ świetle postanowień konstytucyjnych. W przypadku opróżnienia urzędu Prezydenta, osoba wykonująca jego obowiązki czyni to w okresie międzykadencyjnym (a nie do momentu upływu kadencji głowy państwa), tzn. po zakończeniu kadencji dotychczasowego Prezydenta, a przed rozpoczęciem kadencji nowo wybranego Prezydenta ${ }^{29}$.

Wskazane argumenty, oparte przede wszystkim o stosunkowo jasne przepisy polskiej ustawy zasadniczej, nie pozwalają na uznanie za właściwą odmiennej wykładni użytego w art. 5 ust. 2 ustawy o KRS z 2001 r. pojęcia zakończenia kadencji głowy państwa. Nieuprawniona była zatem konstatacja Sądu Najwyższego, w której skład orzekający uznał, że śmierć Prezydenta nie ma takiego samego znaczenia, jak zakończenie kadencji. Śmierć głowy państwa oznacza przecież, zgodnie z wyraźną dyspozycją art. 131 ust. 2 pkt 1 konstytucji, zakończenie kadencji piastuna tego urzędu i nie jest dopuszczalne jakiekolwiek inne rozumienie tej regulacji. Na niepowodzenie jest też skazana próba wykładni art. 5 ust. 2 ustawy z 2001 r. w powiązaniu z ust. 1 tego przepisu, który stanowił, że osoba powołana przez Prezydenta pełni swoją funkcję w KRS bez oznaczania kadencji i może być w każdym czasie odwołana. Jest oczywiste, że oba te przepisy stanowią regulację poświęconą statusowi osoby powołanej w skład Rady przez głowę państwa. Jednakże z przepisu ust. 1, który regulował, jak to już wskazano, dwie inne kwestie (brak oznaczania okresu kadencji i uprawnienie do odwołania tej osoby w każdym czasie), nie da się w żaden sposób wyinterpretować modyfikacji czasu trwania kadencji Prezydenta. Przecież art. 5 ust. 2 był nie-

28 R. Mojak, Instytucja Prezydenta RP w okresie przekształceń ustrojowych 1989-1992, Warszawa 1994, s. 178.

29 Z zupełnie inną sytuacją mamy do czynienia w systemie amerykańskim. Przyjmuje on bowiem zasadę „mandatu związanego z samym urzędem. W tym wypadku opróżnienie urzędu (...) przed upływem (...) kadencji powoduje przejęcie jego urzędu przez (...) wiceprezydenta, który pełni funkcję tylko do czasu trwania kadencji jego poprzednika” (ibidem). 
wątpliwie swoistą wyjątkową regulacją, która miała znaleźć zastosowanie w sytuacjach nadzwyczajnych, np. w przypadku gdy nowo wybrany Prezydent nie dokonałby odwołania członka KRS powołanego przez poprzednio urzędującego Prezydenta, albo właśnie w sytuacji opróżnienia urzędu głowy państwa, a nie unormowanie, które miało modyfikować konstytucyjnie określony czas trwania kadencji Prezydenta w kontekście jednego z jego uprawnień nominacyjnych.

Dowodzenie innego, odmiennego od przepisów konstytucyjnych, rozumienia zakończenia kadencji głowy państwa, nie może być też oparte o argument, w myśl którego to swoiste „trwanie” kadencji zmarłego Prezydenta i uzależnienie biegu trzymiesięcznego terminu ustania członkostwa w Radzie jest spowodowane chęcią skutecznej regulacji prerogatywy nowo wybranego Prezydenta do powołania jednego z członków Rady. Po pierwsze, należy pamiętać, że osoba tymczasowo wykonująca obowiązki Prezydenta korzysta ze wszystkich jego konstytucyjnych uprawnień, z wyjątkiem skrócenia kadencji Sejmu (art. 131 ust. 4 konstytucji RP). Jest oczywiste, że ta regulacja odnosi się również do powoływania i odwoływania członka KRS. Po drugie, nie ma praktycznie żadnego znaczenia argument, w myśl którego uznanie dalszego trwania kadencji zmarłego Prezydenta miałoby służyć respektowaniu woli nowo wybranego Prezydenta, który dopiero po objęciu urzędu będzie miał możliwość powołania członka Rady, skoro powołany przez poprzednią głowę państwa lub też osobę tymczasowo wykonującą obowiązki Prezydenta członek KRS może być w każdym czasie odwołany. Zatem w sytuacji, gdyby nowo wybrany Prezydent nie akceptował członka KRS powołanego przez osobę tymczasowo wykonującą obowiązki Prezydenta, mógł przecież tę osobę odwołać i powołać na to miejsce inną. W tym kontekście nie bez znaczenia jest zwrócenie uwagi na fakt, że w konstytucji RP zostały wprowadzone rozwiązania mające na celu zapewnienie wykonywania funkcji Prezydenta w razie opróżnienia urzędu głowy państwa nie po to, aby były one tylko potencjalną możliwością, nieznajdującą zastosowania ze względu na to, że przyszły Prezydent może mieć inny pogląd na daną kwestię. Przyjęcie założenia, że z takiego względu osoba tymczasowo wykonująca obowiązki Prezydenta miałaby wstrzymywać się z wykonywaniem poszczególnych kompetencji, uczyniłoby instytucję zastępstwa głowy państwa w istocie fikcyjną. 
VI.

W kontekście problematyki wygaśnięcia członkostwa w Radzie osoby powołanej przez Prezydenta należy jeszcze wspomnieć o problematyce zakończenia wypełniania swojej funkcji w KRS przez osobę powołaną przez Marszałka Sejmu (Marszałka Senatu) tymczasowo wykonującego obowiązki głowy państwa. Nie ulega wątpliwości, że zarówno przepis art. 5 ust. 2 ustawy z 2001 r., jak przepis art. 8 ust. 2 trzeciej ustawy o KRS z 2011 r. ${ }^{30}$ odnoszą się expressis verbis do osoby powołanej przez urzędującego Prezydenta, a nie przez osobę tymczasowo wykonującą obowiązki głowy państwa. W związku z tym powstaje pytanie, w jaki sposób rozstrzygnąć kwestię ustania członkostwa w Radzie przez osobę powołaną przez Marszałka Sejmu (Marszałka Senatu), a w szczególności, czy to członkostwo ustaje w ciągu trzech miesięcy po zakończeniu tymczasowego wykonywania obowiązków Prezydenta.

Jak już wyżej wskazano, osoba tymczasowo wykonująca obowiązki Prezydenta nie kontynuuje kadencji uprzedniego piastuna głowy państwa. Należy też dodać, że nie można jej przypisać jakiegoś rodzaju własnej kadencji, która trwałaby pomiędzy kadencjami poprzednika oraz nowo wybranego Prezydenta. Z tego też względu nie jest możliwa taka wykładnia, która prowadziłaby do wniosku o zakończeniu członkostwa w KRS osoby powołanej przez Marszałka Sejmu lub Marszałka Senatu w ciągu trzech miesięcy od zakończenia tymczasowego wykonywania obowiązków Prezydenta. Wykładnia taka byłaby również niecelowa, ponieważ nowo wybrany Prezydent, na co już wyżej również zwracano uwagę, ma przecież prawo odwołania w każdym czasie osoby powołanej w skład Rady. Jest oczywiste, że może dokonać odwołania także w przypadku, gdy nominacja dokonana przez osobę tymczasowo wykonującą obowiązki głowy państwa, z jakichkolwiek względów, nie będzie cieszyć się jego akceptacją. W świetle tych ustaleń należy uznać, że - poza przypadkiem odwołania ze składu Rady członkostwo takiej osoby w KRS wygaśnie w ciągu trzech miesięcy od zakończenia kadencji nowo wybranego Prezydenta.

30 Ustawa z 12 maja 2011 r. o Krajowej Radzie Sądownictwa (t. j. Dz.U. 2016, poz. 976 ze zm.). 


\section{VII.}

Konkludując należałoby stwierdzić jeszcze raz, że w przypadku zaistnienia którejkolwiek z sytuacji opisanych w art. 131 ust. 2 konstytucji RP, mamy do czynienia z opróżnieniem urzędu Prezydenta, co jest równoznaczne z zakończeniem jego kadencji. W związku z tym, zgodnie $\mathrm{z}$ analizowanym art. 5 ust. 2 ustawy o KRS z 2001 w ciągu trzech miesięcy po śmierci Prezydenta Lecha Kaczyńskiego z mocy prawa zakończyła się kadencja członka Rady powołanego przez zmarłego Prezydenta.

Interesujące jest, że kwestia opróżnienia urzędu Prezydenta i jego skutków dla osoby powołanej przez głowę państwa w skład KRS stała się rok później przedmiotem prac parlamentu w trakcie procedury uchwalania trzeciej ustawy o KRS. Choć w senackim projekcie tej ustawy ${ }^{31}$ zawarto przepis art. 9 ust. 2, który miał dokładnie takie same brzmienie, jak analizowany wyżej przepis art. 5 ust. 2 ustawy o KRS z 2001 r., to jednak w wersji uchwalonej przez Sejm (oznaczony ostatecznie jako art. 8 ust. 2) przybrał następującą postać: „Mandat osoby powołanej przez Prezydenta wygasa najpóźniej w ciągu trzech miesięcy po zakończeniu kadencji Prezydenta albo opróżnieniu urzędu Prezydenta Rzeczypospolitej Polskiej”.

W stosunku do tej normy można sformułować co najmniej dwie uwagi. Po pierwsze, ustawodawca wyraźnie odróżnił zakończenie kadencji głowy państwa od opróżnienia urzędu Prezydenta ${ }^{32}$. Jak już wyżej zauważono, nie jest to rozróżnienie poprawne, gdyż opróżnienie urzędu jest równoznaczne z zakończeniem kadencji Prezydenta RP. Po drugie, również na tle aktualnego stanu prawnego nie jest możliwe sformułowanie twierdzenia, w myśl którego w przypadku opróżnienia urzędu Prezydenta kadencja głowy państwa wygasa dopiero po upływie okresu, w którym Marszałek Sejmu (Marszałek Senatu) tymczasowo wykonuje obowiązki Prezydenta oraz - co za tym idzie - że dopiero od tego momentu biegnie trzymiesięczny termin wygaśnięcia mandatu

31 Druk sejmowy 3364/VI kad.

32 Postulat rozróżnienia tych dwóch sytuacji (zakończenia kadencji na skutekjej upływu oraz opróżnienia urzędu) został zgłoszony przez Radę Ministrów. Zob. Stanowisko Rządu wobec senackiego projektu ustawy o Krajowej Radzie Sądownictwa (druk nr 3364), s. 5, http:// orka.sejm.gov.pl/Druki6ka.nsf/0/77C871795927D074C12577EE00267C24/\$file/3364-s. $\operatorname{pdf}(27.07 .2017)$. 
osoby powołanej w skład KRS przez głowę państwa. Pomimo bowiem tego, że ustawodawca w dalszym ciągu posługuje się dwoma pojęciami (tj. pojęciem zakończenia kadencji Prezydenta oraz opróżnienia urzędu Prezydenta), to jednak $\mathrm{z}$ tego rozróżnienia nie wyprowadza odmiennych skutków prawnych. Zgodnie bowiem z art. 8 ust. 2 ustawy o KRS z 2011 r. mandat osoby powołanej w skład Rady przez Prezydenta wygasa najpóźniej w ciągu trzech miesięcy nie tylko w przypadku upływu kadencji głowy państwa w konstytucyjnym terminie, ale także we wszystkich przypadkach przedterminowego jej zakończenia.

\section{Literatura}

Balicki R., [w:] Komentarz. Konstytucja Rzeczypospolitej Polskiej, red. M. Haczkowska, Warszawa 2014.

Banaszak B., Konstytucja Rzeczypospolitej Polskiej. Komentarz, Warszawa 2009.

Ereciński T., Gudowski J., Iwulski I., Prawo o ustroju sąów powszechnych. Ustawa o Krajowej Radzie Sadownictwa. Komentarz, Warszawa 2010.

Garlicki L., uwaga 5 do art. 187, [w:] Konstytucja Rzeczypospolitej Polskiej. Komentarz, t. IV, red. L. Garlicki, Warszawa 2005.

Grajewski K., Prezydencka kompetencja do powoływania członka Krajowej Rady Sadownictwa - prerogatywa czy uprawnienie zwykte?, [w:] Zagadnienia prawa konstytucyjnego. Polskie i zagraniczne rozwiązania ustrojowe. Ksiega jubileuszowa dedykowana Profesorowi Dariuszowi Góreckiemu w siedemdziesiąta rocznicę urodzin, red. K. Skotnicki, K. Składowski, A. Michalak, Łódź 2016.

Grajewski K., Pułło M., Skutki wadliwości uchwał Krajowej Rady Sąownictwa w kontekście wygaśnięcia mandatu jednego z jej członków w związku z opróżnieniem urzędu Prezydenta RP, „Krajowa Rada Sądownictwa” 2011, nr 1.

Mojak R., Instytucja Prezydenta RP w okresie przeksztatceń ustrojowych 1989-1992, Warszawa 1994.

Oświadczenie Prezydium Krajowej Rady Sądownictwa z 21 września 2010 r. (maszynopis). Pęk R., uwaga 5 do art. 8, [w:] M. Niezgódka-Medek, R. Pęk, Krajowa Rada Sądownictwa. Komentarz, Warszawa 2013.

Popławska E., Opróżnienie urzędu Prezydenta RP (art. 128, 131), [w:] Konstytucja Rzeczypospolitej Polskiej. Komentarz encyklopedyczny, red. W. Skrzydło, S. Grabowska, R. Grabowski, Warszawa 2009. 
Sprawozdanie z posiedzeń Podzespołu do spraw Reformy Prawa i Sąów „Okragłego Stołu” (brak miejsca i daty wydania) http://okragly-stol.pl/wp-content/uploads/2014/04/05_ sprawozdanie_prawo_sady.pdf.

Stanowisko Rzadu wobec senackiego projektu ustawy o Krajowej Radzie Sadownictwa (druk nr 3364), http://orka.sejm.gov.pl/Druki6ka.nsf/0/77C871795927D074C12577EE00267C24/\$file/3364-s.pdf.

Stanowisko w sprawie reform politycznych (brak miejsca i daty wydania), http://okragly-stol.pl/wp-content/uploads/2014/04/01_stanowisko_polityka.pdf.

Szczucki K., [w:] Konstytucja RP. Tom II. Komentarz. Art. 87-243, red. M. Safjan, L. Bosek, Warszawa 2016.

Witkowski Z., Prezydent Rzeczypospolitej Polskiej, [w:] Prawo konstytucyjne, red. Z. Witkowski, Toruń 2006. 